\title{
真空スパッタリング用イオン源とその応用*
}

\author{
田 村一三 三**
}

(昭和 46 年 1 月 28 日受理)

A New Ion Source for Vacuum Sputtering of Thin Films and Its Application

\section{Hifumi TAMURA}

(Central Research Laboratory, Hitachi Ltd. Kokubunji, Tokyo 185)

(Received Jan. 28, 1971)

The present author have deen developed a new type ion source for vacuum sputtering which includes an electrostatic deflector. The ions emitted from the ion source are deflected by a set of deflecting electrodes, one of these is at the anode potential and the other at accelerating potentiál.

The ion beam has been used to sputter conducting and insulating target materials. From these experimental result it is found that the deposition rate of a given material is approximately proportional to the primary ion current for given accelerating voltage. Typical rate of deposition of nickel film at distance of $7 \mathrm{~cm}$ from the target with a $500 \mu \mathrm{A}, 5 \mathrm{KV}$ ion beam of $3 \mathrm{~mm}$ diam is $\sim 40 \AA / \mathrm{min}$.

As a practical application of the method, the nickel 40\% - copper 54\% alloy film for strain gauge was deposited by the two separate ion gun simultaneously. The content of these chemical composition was regulated by the primary ion beam current.

\section{1. 緒 言}

スパッタリング現象を利用して，金属扣よび絶縁物の 薄膜を生成させる方法は, 現在実用的に広く利用されて いる。スパッタリング現象を利用した薄膜生成法は，蒸 発粒子の運動エネルギーが大きいために，下地との付着 力が強い1). 薄膜の生成過程においてコアレッセンスの 機会を増すなどの多くの望ましい特徵をもっていること が知られている。しかし一般に利用されているスパッタ リング技術は, 装置の簡単化とコスト低減の理由から, 低真空, 低エネルギーのグロー放電の雲囲気を使ってい る。このような低真空に拈いては, スパッタ原子は，ガ スとの衝突を多くくり返し，その結果，エネルギーを失 ない力向がランダムになり，スパッタ膜の構造特よびそ の特性にスパッタ過程がどのように効いているかを推定 することが困難である。おた従来の放電を利用したスバ ッタ技術に和いては, 複数元素のスパッ夕速度を個々に

* 昭和 45 年 4 月 1 日 応物学会講演会に拉いて講演

** 日立中央研究所 (東京都国分寺市東恋ヶ䆶 1 の 280)
測定しながら，所望の成分をもつ薄膜をうることが困難 であった。

筆者は, 上記のような観点から新しいスパッタリング 用イオン銃を試作し，その諸特性について検討した。利 用したイオン銃は, 従来の Ardenne ${ }^{2}$ 形を変形したもの であり,イオン鋶より放出したイオンビームを，一方を 引き出し電極に他方をアノードに取りつけた 2 枚の偏向 電極により L形に曲げ，スパッタ材料に照射させる方式 を採用した，同じ考えにもとづいた電子線蒸着用電子 銃 ${ }^{2}$ についてはすでに報告した。このイオン銃は，円筒 状をしたイオン銃ユニットに二個取りつけられて抮り. これにより二成分元素のスパッタリングをそれぞれ独立 にかつ同時に行なえるようにした，次に試作したイオン 銃ユニットを使い, スパッ夕速度を一次イオン電流およ び二次電子電流の関数として測定し, 両者が比例関係に あることを見出した。

\section{2. イオン銃}

イオン銃については, すでに種々の形式のものが開発 され，実用化が行なわれている，乙かし薄膜生成に利用 
した例は少ない，従来利用されている代表的なイオン銃 として，(1)高周波型と，(2)デュオプラズマトロン型イオ ン銃があるが，筆者は，(a)イオン源が小さくできる，

(b)イオン電流密度が高い, (c) 装置が比較的小形にで きる等の理由から(2)を採用し，これに改良を加えた。

\section{1 イオン銃およびイオン銃ユニットの試作}

Fig. 1 (a), (b) 飞試作したイオン銃の断面図と外観写 真を示す。その構成は, デュオプラズマトロン型イオン 銃と放射したイオンビームを偏向するための偏向電極か ら成っている，デュオプラズマトロン型イオン銃につい ては, 寸でによく知られているので, 詳細については省 略する. カソードにはイオン銃の過熱を考虑して $\mathrm{BaO}$ 系 の酸化物を採用した。 アノードの孔径は, 取り出しうる イオン電流に関係するので, $0.3,0.5,1 \mathrm{~mm} \phi$ の 3 種を 作った。実験では主に $1 \mathrm{~mm} \phi$ を使用した。その他イオ ン銃の寸法はFig.1 亿示す通りである。

イオン銃から放射したイオンビームは, 二枚の偏向電 極の電場により， L型に偏向させ，スパッタ材料に照射 させる。 この場合, アノードと引き出し電極の形状は, pierce 形状になっていて材料上に，イオンビームを集束 させるように設計した，Pierce ${ }^{4}$ は，平円板状のカソー ドから零エネルギー（初速度が零）で放出された荷電粒 子流は，電極系を適当にす札ば，平行ビームとして取り 出せることを示した。この場合, 電流密度 $J\left(\mathrm{~A} / \mathrm{cm}^{2}\right)$ は，次式で与兄られる。

$$
J=\frac{5.44 \times 10^{-8} \phi^{\frac{3}{2}}}{M^{\frac{1}{2}} Z^{2}}
$$

ここに $\phi:$ 加速電圧 $(V), M$ : イオンの質量数,

$Z:$ アノードと引き出し電極間の有効距離 $(\mathrm{cm})$

イオンビームの偏向は, 静電型を採用し, 一方の偏向 電極は, アノードに, 他方の偏向電極は, 引き出し電極 にそれぞれ取りつけられている。したがってイオンビー ムの偏问量 $Y$ は次式で与兄られ。

$$
Y=\frac{V_{p} \cdot L \cdot l}{2 V \cdot d}
$$

ここに $V_{D}:$ 偏向電生 $(\mathrm{V}), V:$ 加速電圧 $(\mathrm{V})$

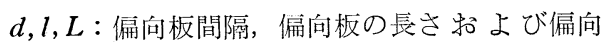
板中心よりターグットまでの水平距離

一方, 筆者の場合は, 偏向電圧として加速電圧をその まま利用しているので, $V_{D}=V$ となり, 偏向量 $Y$ は, $L l / 2 d$ で与兄られる.すなわらビームの偏向量は, 偏 向電極の形状, 寸法のみに依存し, 加速電压が変動して も(例觉ば交流) 偏问量は, 常に一定になり, イオンビ 一ムの照射位置は不変である。

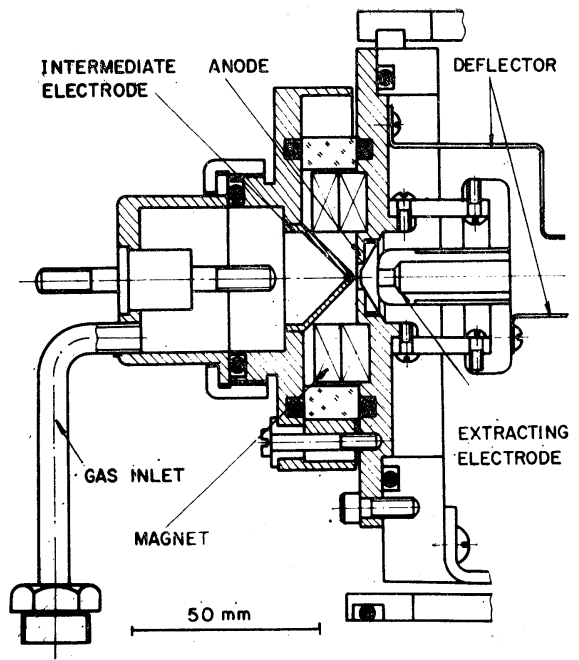

(a)

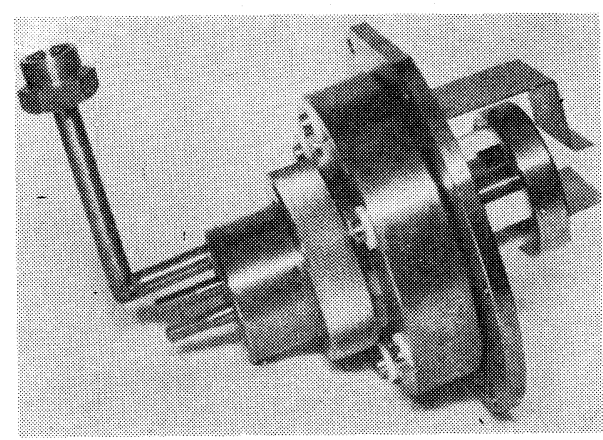

(b)

Fig. 1 Schmatic diagram of newly designed ion gun.

Fig. 2 亿，上記イオン銃を二個取りつけたイオン銃二 ニットの断図面を示す，イオン銃ニニットは，独立に配 置した二元素を同時にスパッタさせ, 両者の混合膜を作 ることを目的として試作した。すなわち二つのイオン銃 より放射したイオンビームは，关机ぞれ異なった場所に 配置したターゲットを照射できるようになっている、イ オン銃ニニットは, 從来の蒸着装置のベースとベルジャ の間に簡単に取りつけられるように設計した。 Fig. 3に イオン銃ニニットを従来の標準蒸着装置に取りつけた状 態を示す，イオン銃は，正面から見て左右に配置できる ようになっている。

\section{2 イオン銃の諸特性}

イオン銃の特性は Fig. 4 に示与回路により測定した. 従来のイオン銃との相違は, 簡単化拈よびュスト低隇の 目的で，放電々源に交流を利用していることである。し 


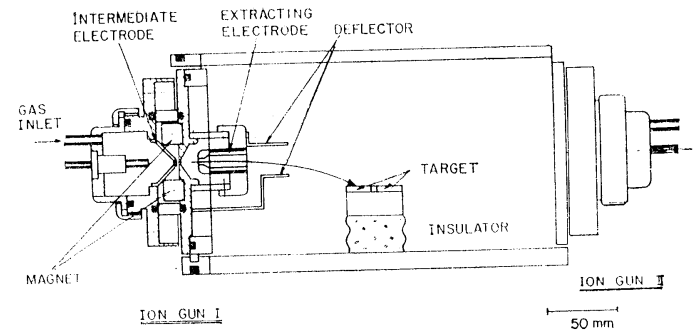

Fig. 2 Construction of newly designed ion gun unit.

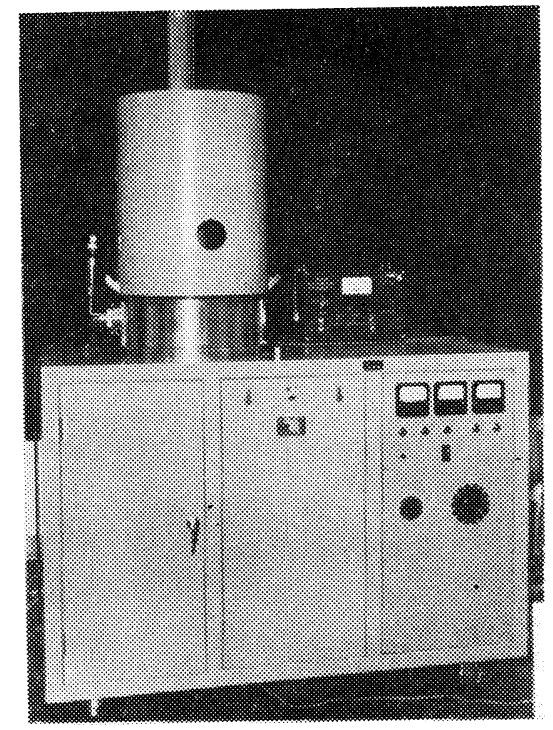

Fig. 3 External view of the evaporater equipped with gun unit.

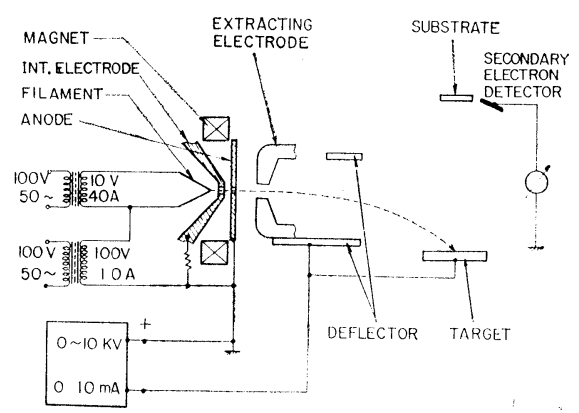

Fig. 4 The electrical circuit for the ion gun.

かも放電は $100 \mathrm{~V}$ 以下で起動できるように䉓極類を設計 した.

はじめにアノードとカソード間の放電流と放射イオ ン電流の関係を測定した。アノード中間電極間の磁場強 度を $3 \mathrm{KG}$ 㐨よび無磁場の場合について，イオン加速電 压を $5 \mathrm{KV}$ ，イオン銃部の真空度 $\mathrm{P}$ を $10^{-2}$ Torr (Arの

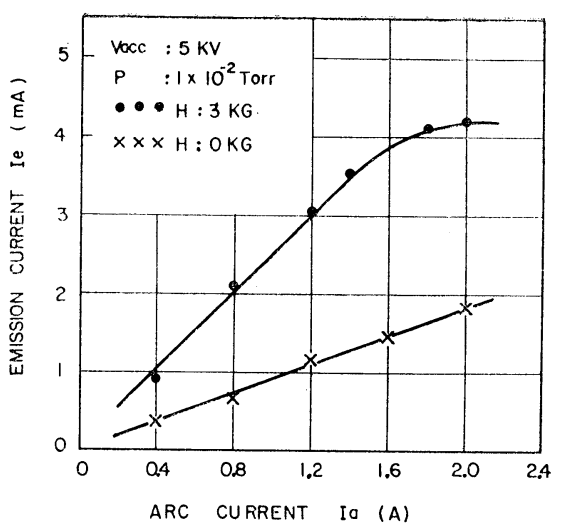

Fig. 5 The variation of the emission current with the arc current.

需囲気）に保ち，放電々流 $\mathrm{I}_{\mathrm{arc}}$ の関数として放射イオン 電流を測定した結果を Fig. 5 に示す，放電々流と放射イ オン電流の関倸は, (1)無磁場の場合と, (2)中間電極と了 ノード間に軸方向磁場を加えた場合で異なり，(1)の場合 放射イオン電流は, 放電々流の增加とともに比例的に増 加してゆくが，3 KG の磁場を加光た(2)の場合には全体 的に放射イオン電流が約 2 倍に增加し，かつ放電々流が 1.6 A 以上では飽和する傾向を示す。 (2)のイオン電流の 飽和はプラズマより取り出せるイオン電流に制限がある ことを意味する，この実験から，放電々流として交流を 利用した場合でも, 従来の直流放電とほ涪同じ特性をる つことがあきらかとなった。

Fig. 6 亿加速電压の関数として, 放射イオン電流と到 達イオン電流を測定した結果を示す。到達イオン電流は 点線で示した. Fig. 6により, 加速電圧 $\mathrm{V}_{\mathrm{arc}}<2.5 \mathrm{KV} て ゙$ は式(1)に示したように，放射イオン電流 Ieは、 $\mathrm{V}_{\mathrm{arc}}{ }^{\frac{3}{2}}$ に したがって増加していることがわかる。しかし加速電压 が $3 \mathrm{KG}$ 以上になると飽和する傾问を示す。すなわちこ の領域では, イオン銃は温度制限領域で動作しているこ とを意味与る。到達イオン電流 $\mathrm{I}_{\mathrm{t}}$ は，引き出し電極を 通過したイオン電流をフォラデケージにより測定したも のである。イオン電流 $\mathrm{I}_{\mathrm{t}}$ は, 放射イオン䉓流が増加し,

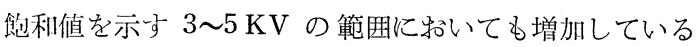
ことがわかる。これは加速電圧が高くなったために， イ オンビームの集束性がよくなり，イオン電流效率が增加 したことによるるのと考光られる。

Fig. 7 にイオン銃部の真空度と放射イオン䉓流の関保 を測定した結果を示す。実験条件は，加速電圧を $5 \mathrm{KV} に$ アノードと中間電極間の磁場 $\mathrm{H}$ を $3 \mathrm{KG}$ V保った。実験 により, 放射イオン電流は, 真空度に依存し, 最適条件 が存在することが明らかになった,すなわち $2 \sim 3 \times 10^{-2}$ 


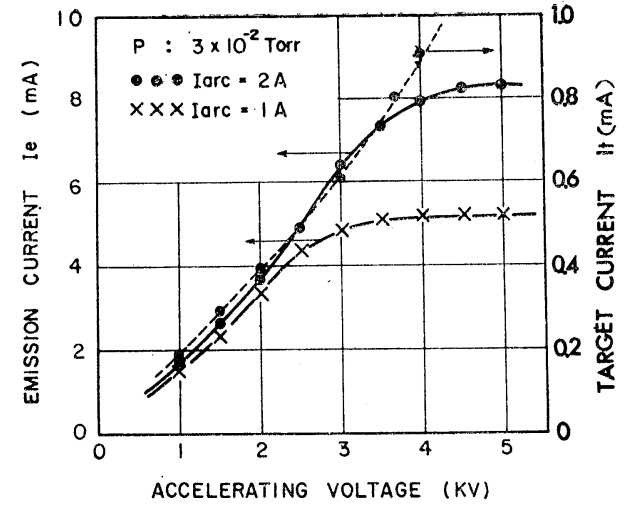

Fig. 6 The variation of the ion current with the accelerating voltage.

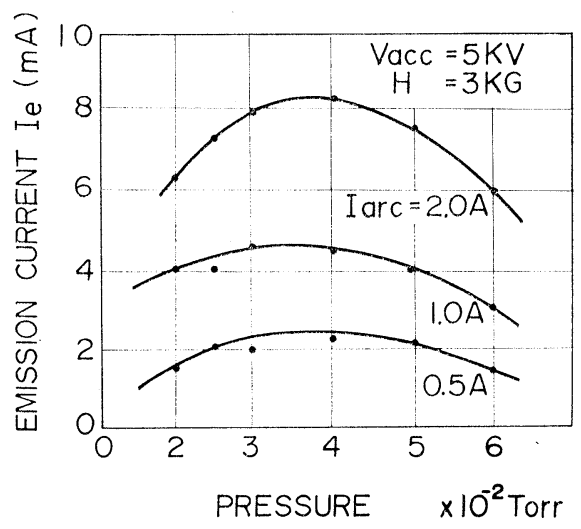

Fig. 7 The variation of the emission current with the pressure in arc chamber.

Torr あたりにイオン電流の最大值が現われている。な おイオン銃部の真空度 $\mathrm{P}$ は，実測が困難なため，ガス 流量と排気速度の測定から推定した。実験結果より，イ オン源に括ける電離度を計算すると 30 ４0\%になり， 従来えられている80 90\%に比較して低い值であるが, この原因についてはあきらかでないが，放電々圧を交流 にしたことが大きな原因であろうと考觉られる。

\section{3. 真空スパッタリングへの応用}

\section{1 一次イオン電流とスパッタ速度}

試作したイオン銃ユニットを従来の真空蒸着装置にと りつけて，一次イオン電流とスパッタ速度の関係を実測

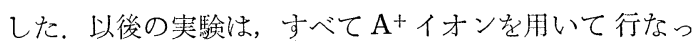
た、イオン銃部の真空度は， $10^{-2}$ Torrであり，スパ ッタ材料特よびサブストレートの配置してある真空鐘は スパッタ時常に $5 \times 10^{-5}$ Torr 以下に保った。 したがっ

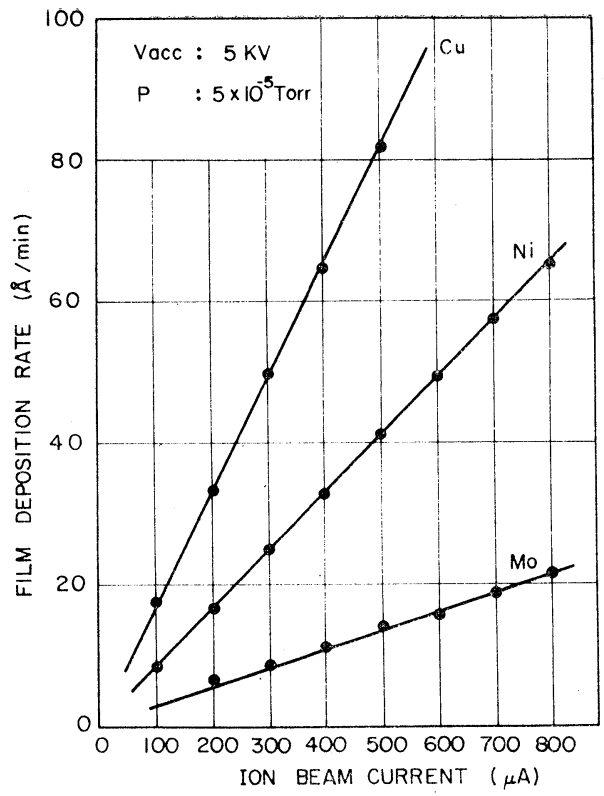

Fig. 8 The variation of the deposition rate of $\mathrm{Cu}, \mathrm{Ni}$, Mo films with the ion beam corrent.

てスパッタされた原子は, 残留原子や分子との散乱は行 なわれず, 発生した時の初速度を保って下地に到達す る. 一方従来のスパッタリング装置では, $10^{-4} \sim 10^{-2}$ Torr のガス中でスパッタさせるので, スパッタ原子 は, 他原子和よび分子と衝突をくり返し, 速度を失って 下地に到達し，付着するものと考えられる．この点が従 来のスパッタリングと真空スパッタリングの相違点であ る.

Fig. 8 は加速電圧を5KVに保ち, 照射イオン電流とス パッタ速度の関係を測定した結果を示したものである. スパッタ材料としては, 高純度 $(99.98 \%)$ の銅, ニッ ケル，モリブデンを用い，これを厚さ $1 \mathrm{~mm}$, 長さ $15 \mathrm{~mm}$ 幅 $10 \mathrm{~mm}$ の長方形の板状に加工して使用した. スパッ タ材料と下地との距離は常に $70 \mathrm{~mm}$ に保った. イオンビ 一ムのスパッタ材料への入射角は約 20 度である。実験で は, 入射一次イオン電流と二次電子電流を同時に測定し たが，入射一次イオン電流と二次電子電流の比例性はき わめてよいことがあきらかになった。

スパッタ速度は, 付着した膜の厚さをくり返し干渉計 により測定し, 觉られた值をスパッタ時間で除して算出 した。使用したくり返し干渉計の精度は $40 \AA ̊$ である。実 測したスパッタ膜の厚さは数 $1000 \AA ̊$ であり, 膜厚の测定 愦差は $5 \%$ 以下である. Fig. 8 から，次のようなことが あきらふたなった。 
（1）スパッ夕速度は，入射一次イオン䉓流拈よび二次 電子電流に比例し, 入射一次イオン電流拈よび二次 電子電流を検出ることにより, スパッタ速度を精度 よく測定できる.

（2）スパッ夕速度は，銅，ニッケル，モリブデンの順 に遅くなって抒り、少でに測定されているスパッタ リング効率 (Atoms/ion) の值の相刘比にほぼ一致 していることがわかる.

Fig. 9 は, 一次イオン電流を $400 \mu \mathrm{A}$ に保占, 一次イ オンのエネルギーの関数として，スパッタ速度を測定し た結果を示したものである.イオンビーム電流の調整は 放電々圧を変兄て行なった，イオン電流を一定に保ち， 加速電圧を $1 \mathrm{KV}$ から $7 \mathrm{KV}$ まで変化させるとスポット 径は約 $20 \%$ 減少することが観測されたが，この種の実験 には余り影響がないものと考兄られる. Fig. 9 から, 一 次イオン加速電圧が $4 \mathrm{KV}$ までは, スパッタ速度は一次 イオンのエネルギーに比例して增加してゅくが， $4 \mathrm{KV}$ 以上ではスパッタ速度が飽和する傾问寺示す。この原因 についての詳細は不明であるが，定性的には、イオンの スパッタ材料中への透過が考兄らる。

\section{2 二成分薄膜の生成}

複数成分の薄膜を生成させる場合, 複数成分の化合 物材料を蒸着またはスパッタさせるとそれぞれの元素 の蒸発速度およびスパッタ効率の差により, 材料とは 成分比の異なる薄膜が生成されてしまう。また複数成分 を独立に蒸発させる方法もあるが，この場合には、個 た の蒸発速度を独立にかつ精度よく制御与る方法がない。 このことは薄膜工学に和ける一つの問題点とされてい る.

ここでは, 二成分薄膜の生成について, 実験結果を記 す. 3.1 亿記した実験結果により, スパッタ速度は一次 イオン電流に比例して増加することがわかった。この結 果を用いて, 二成分元素のスパッ夕速度を独立に制御し て, 所望成分和よび膜厚の薄渕を生成させる方法につい て予備実験を行なった. 実験方法は, Fig. 2 に示した原 理に従って, 同時に二つのイオン銃を働かせ, 近接して 配置した二つのスパッタ材料にそれぞれ別々に照射し， これを同一基板上にスパッタさせる.この場合，目標に しているスパッタ速度に合うように，スパッタリング效 率を考虑して, 一次イオン電流をきめる。このように雨 者の一次イオン電流がきまったのち, シャッタを開き, あらかじめさめた臊厚になるように一定将間だけスパッ タさせる.

上記のような方法を用いて，ストレンゲージの材料で ある銅とニッヶルの混合膜を生成させたので，以後これ について記す、ストレンゲージとして要求されることは
温度係数が小さいこと打よびゲージ率が大きいことであ り，この条件をみたす材料として従来から銅 $54 \%$, ニッ ケル $46 \%$ の化合物が使われていた。 スパッタ材料として は，3.1の穾験に使用したものと同じ純度の銅とニッケ ルを用いた。实験条件は，スパッタ材料と下地との距離 を $70 \mathrm{~mm}$ に固定し，銅材料に，400 $\mu \mathrm{A}$ ，ニッケルに 170 $\mu \mathrm{A}$ イオンビームを照射した。 こ机らの値は, Fig. 8の 実険絬果と阔者の混合比を考慮してきめた、スパッタ時 間は約 5 分である。慕厚は $6000 \AA$ 程度であり，スパッタ 速度から学想した値にかなり近い。

次にこのようにして生成させた薄膜について，抵抗温 度係数の測定を行なった. その結果を Fig. 10 に示す.

F.g. 10には銅54\%，ニッケル $46 \%$ の化合物を蒸着材料と して電子線蒸着した場合と従来の方法でスパッタさせた 場合の膜の温度特性も同様にプロットしてある. また参 考のためにバルク材料の抵抗一温度特性る示してある.

Fig.11に用いた材料, 電子線蒸着した膜和よび真空ス パッタした膜をイオンマイクロアナライザ5により分析 した結果を示す。この分析結果から，電子線蒸着により 作製した脱では分溜蒸発が起り, 材料との組成変化がい らじるしいが，このようなプロセスで真空スパッタ法で えられた膜は, ストレーンゲージ用バルク材料とほとん ぞ同じ組成をもつことがわかった。

以上の実験結果により, 従来の電子線蒸着法招よびス

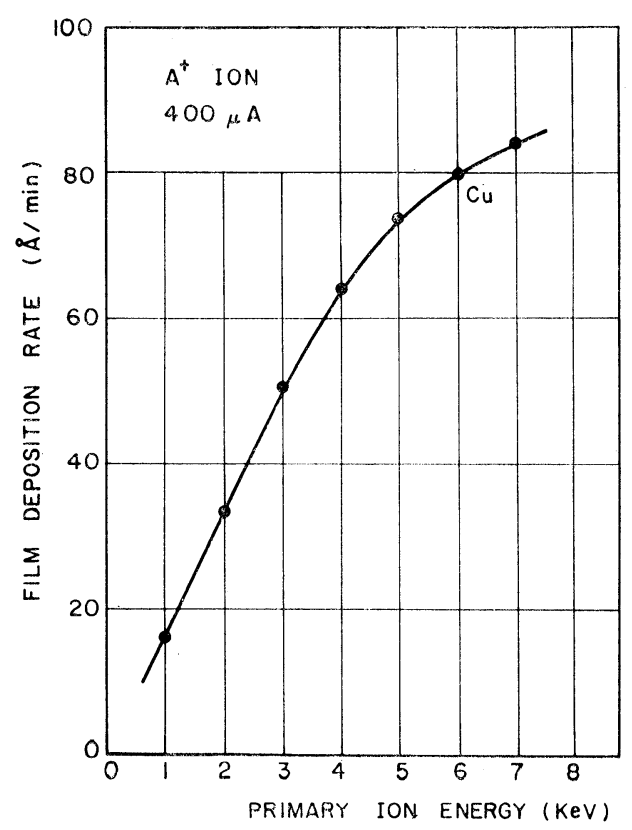

Fig.9 The film deposition rate as a function of enery for bonbardment by argon ion. 


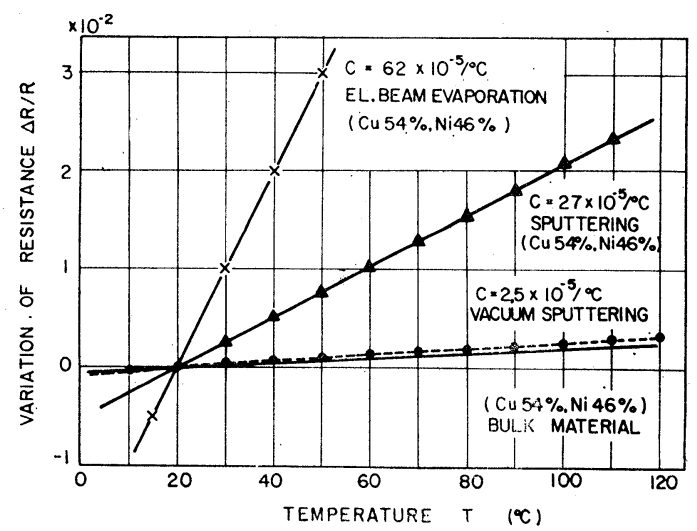

Fig. 10 The variation of the resistance with the temperature.

パッタリング法により化合物の蒸着を行なうと, 分溜蒸 発执よびスパッタリング効率の美違によりもとの材料と 組成扣よび性質のいらじるしく異った膜が壳られるが, 真空中でスパッタ率に応じて，スパッタさせる真空スパ ッタ法ではほぼバルク材料と同様の組成和よび温度特性
をもつ膜が兄られることがあきらかとなった。

\section{3 薄膜生成への散乱電子の影響}

イオン銃の使い方として(1)イオン銃のアノードを接地 電位で使用し，スパッタ材料に負の高圧を印加ずる場合 おるび（2）イオン銃を正の高压に，スパッタ材料を接地 電位で利用する場合がある。(1)はイオン銃を接地電位に 保ら利用するため高圧端子が一本ですみ, 装置が簡単に なる特徵があり，われわれはこれを採用した。しかし(1) では発生した二次電子が加速されて下地に到達し, 悪影 響を拈よぼす、Fig.12に(1)の場合にえられた銅、ニッケ ル，モリブデン，薄膜の表面に発生した放電による亀裂 模様を示す，下地としてはスライドガラスを用いた。 そ の他の条件は図中に示した通りである。亀裂の模様は物 質の種類, スパッタ速度和よび一次イオンのエネルギー などにより異なり複雑である。このような二次電子の覀 影響は下地を電気的に絶縁することによりさけられるこ とが実験からあきらかになった。すなわち下地に带電し ても接地部との間で放電を起こさなければこのような亀 裂は生じない，一般に軽元素物質は，二次電子放射が少
(a) bulk
(b) spputtered film
(c) evaporated film

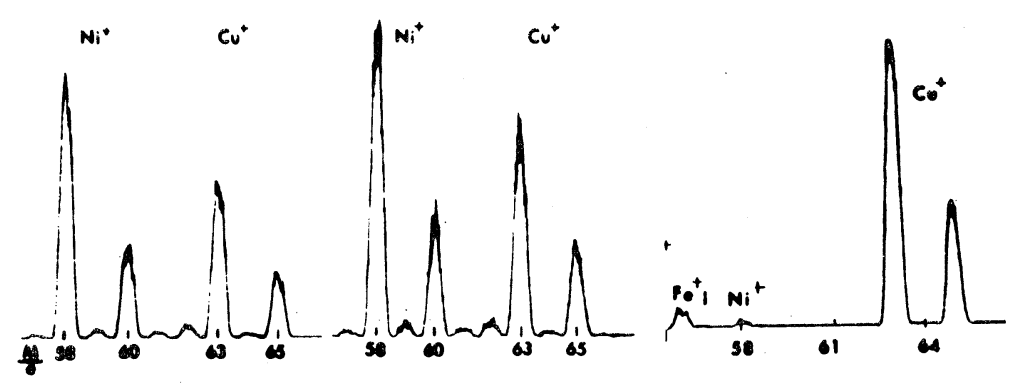

Fig. 11 Mass spectra of $\mathrm{Ni}-\mathrm{Cu}$ alloy.

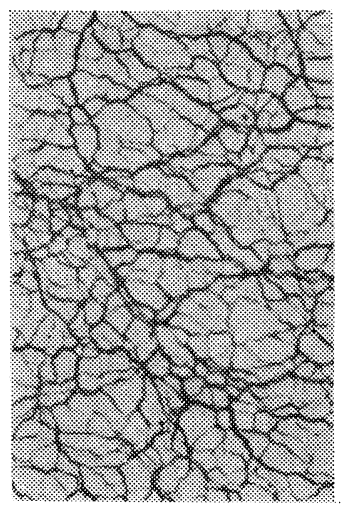

$\mathrm{Cu}$

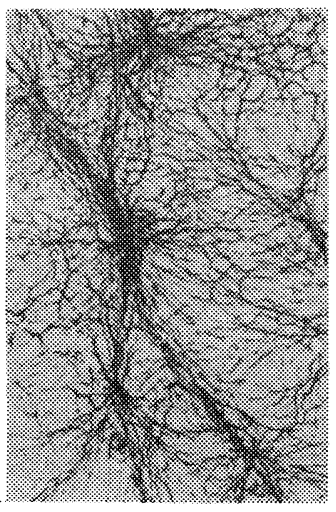

$\mathrm{Ni}$

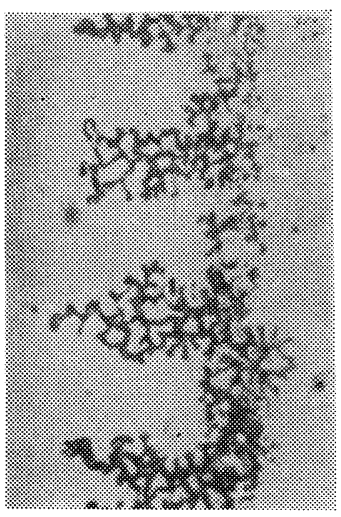

Mo

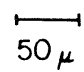

Fig. 12 Micrgraph of a Lichtenberg patterns of a vacuum sputtered $1000 \AA$ films deposited on quartz substrate at the room temperature. 
ないためその影響も比較的少ない，二次イオンの薄膜生 成への影響についてはすで詳細を報告した ${ }^{6)}$.二次イ オン電流は二次電子電流に比較してきわめて少く $\left(10^{-2}\right.$ 〜 10-3 程度)，乙の種の実験では無視できるものと考光 られる. (2)の場合. 二次電子は発生するが基板には到達 できず薄膜生成への悪影響はない.

\section{4. 結 言}

新しい真空スパッタリング用イオン銃の試作とその応 用について記したが，その内容を要約すると次のように なる、まず装置に関しては

(1) 真空スパッタリング用イオン銃は放電々源として 商用周波数の交流が利用できるので, 装置の簡単化 物よびュスト低隇が期待できる。

(2) スパッタ材料执よび下地から直接イオン源が見觉 ないように設計しているので, イオン源からの污染 はない。

(3) イオンビームの偏向は, 加速電圧をそのまま利用 しているので, 加速電圧の変動があってもビームの 照射位置は不変である。

などの特徴がある．次に応用に関しては

(a) 物質によるスパッ夕率 (Atoms/ion) が一定し ているので, スパッタ速度を一次イオン電流抒よび
二次電子電流により測定できる.

(b) (a)の原理にもとずき，二元素のスパッタリング 速度を制御することにより，所望の成分比に近い值 をもつ二成分薄膜（銅一ニッケル合金膜）をうるこ とができた。

（c）イオン鋶を接地電位に，スパッタ材料に負の高 圧を印加する方式では二次電子が薄膜生成に悪影響 を与えるが，下地を電気的に絶緑することにより簡 単にさけられることがあきらかになった。

㐨わりにのぞみ，ご指導いただいた日立中研片桐信 二郎博士に深謝致します。

\section{[文 献]}

(1) R. B. Bellser : Phys. Rev., 92 (1953) 1098.

(2) M. Von Ardenne: Tabellen der Eleckfronenphyisk, Ionephysik und Ubermikroskopie, 1 (1956) 635.

(3) 田村 : 応用物理, 38 (1969) 574 .

(4) J.R. Pierce : Theory and Design of Electron Beams Van Hostrand.

(5) K. Ogata, T. Hayakwa : Recent Devlopments in Mass Speclroscopy(19699).

(6) 田村, 森. 木村 : 真空, 9 (1966) 17. 